\title{
Zmiany zasad odpowiedzialności prawnej przedstawicieli wybranych grup zawodowych w wyniku rozwoju nauk nad mózgiem i neuroscience
}

\section{Cel pracy}

Celem opracowania jest przedstawienie i krytyczne omówienie pojawiających się na Zachodzie propozycji zmian w zakresie odpowiedzialności prawnej ze względu na odkrycia naukowe w dziedzinie neuronauk (neuroscience) oraz badań nad mózgiem. Prezentowane rozważania dotyczą przedstawicieli wybranych grup zawodowych w następujących dziedzinach: transport publiczny, medycyna i służba zdrowia, służby specjalne i wojsko. Dotyczą także tzw. obowiązku poznawczego wzmocnienia i zaostrzenia odpowiedzialności prawnej dla tych osób. Propozycje zmian w prawie, o których mowa, mogą wydawać się kontrowersyjne, a ich ostrożna i konstruktywna krytyka jest wskazana.

\section{Badania nad mózgiem}

Badania nad mózgiem oraz neuronauki są bardzo rozwinięte nie tylko na Zachodzie (np. w Cambridge w Wielkiej Brytanii ${ }^{1}$ czy w wielu ośrodkach w USA), lecz także w Polsce. Fascynacja wizją odkrycia, jak naprawdę działa i funkcjonuje mózg, obezwładnia wielu naukowców i myślicieli. Wiele było już podobnych fascynacji możliwościami, które daje nam nauka, chociażby w XIX w. Dziś odkrycie tego, jak funkcjonuje mózg, w jaki sposób myślimy, jak podejmujemy decyzje, jak procesy zachodzące w mózgu wpływają na nasze zachowanie - jest celem wielu projektów badawczych. Mózg jest najważniejszą częścią systemu nerwowego. On odpowiada za nasze decyzje, które oceniamy także później na gruncie prawa czy moralności. Ale jak on działa? Czy może działać lepiej? Czy można go odpowiednio stymulować, by wpływać na pożądane ludzkie zachowanie albo by niwelować, ograniczać,

${ }^{1}$ Cognition and Brain Sciences Unit jest większy i bardziej aktywny naukowo niż słynny Wydział Filozofii tamże. 
zahamować te zachowania ludzkie, które uważa się za niepożądane? Nie bez powodu wspaniała książka wybitnego neurobiologa Jerzego Vetulani jest zatytułowana: Mózg: fascynacje, problemy, tajemnice ${ }^{2}$. Jest to dziedzina zasadniczo wychodząca poza dotychczasowe rozważania z zakresu filozofii umysłu (patrząc od Kartezjusza do Donalda Davidsona, Wolfa Singera, Michaela Quante czy Marxa Urchsa), która - moim zdaniem - jest mocno spekulatywna w porównaniu $\mathrm{z}$ badaniami nad mózgiem prowadzonymi przez neuroscientists (neuronaukowców) ${ }^{3}$.

Wspomniany J. Vetulani słusznie jednak podkreśla coś, co jest istotne z punktu widzenia ludzkiej odpowiedzialności za czyny:

Człowiek nie jest niewolnikiem własnych genów, ale może świadomym wysiłkiem wzmacniać lub anulować ich wpływy. Fakt, że jesteśmy tworami biologicznymi, nie oznacza, że nie mamy wolnej woli i nie ponosimy odpowiedzialności za nasze zachowanie ${ }^{4}$.

Dość oryginalna to myśl w czasach, gdy coraz więcej poglądów głosi fikcję wolnej woli, jej chrześcijański pejoratywny składnik, odpowiedzialność prawną mózgu (a nie człowieka, który ma wolną wolę) oraz jakiś wszechmocny determinizm w naszych działaniach. J. Vetulani, co istotne, odrzuca wizję Nowego Wspaniałego Świata (NWŚ) ze skanowaniem myśli i daleko idącą ingerencją w prywatność, ale wie, że przeciwnicy NWŚ nie są obecnie w najlepszej sytuacji ${ }^{5}$. Paradoksalnie, badania neurobiologów prowadzą do wniosku, że człowiek jest wyposażony nie tylko w „gramatykę języka”, która umożliwia nauczenie się mowy, lecz także w „gramatykę moralności”, która daje zdolność tworzenia i przestrzegania systemów moralnych albo stanowi o tym, że wiemy, co jest dobre, a co jest złe i czego robić nie powinniśmy ${ }^{6}$. Notabene, mocno krytykowany we współcześnie panującej antyklerykalnej i ateistycznej modzie Kościół katolicki głosi od wieków, że moralność, prawo boskie są wyryte w sercu każdego człowieka, że jest to coś wrodzonego. I to jest powód, iż ludzie różnych kultur, ras, religii wiedzą, co jest dobre, a co złe. Odrzucając zarzut o zbyt irracjonalny charakter tez pracy, podążajmy wiernie za J. Vetulanim. Głosi on, że „funkcjonujący mózg jest niezbędny dla wyrażenia się duszy”. I dodaje:

Z punktu widzenia współczesnego neurobiologa pytanie, czy umysł istnieje jako byt samoistny, czy też jest po prostu pochodną skoordynowanego działania komórek mózgowych, jest nienaukowy i nieistotny. Bez względu na możliwość niezależnego istnienia duszy, nie ma ona żadnej szansy, by wyrazić się bez działającego mózgu .

2 J. Vetulani, Mózg: fascynacje, problemy, tajemnice, Kraków 2011.

3 Por. np. interesujące, teoretyczne, ważne, ale też czasami mocno spekulatywne rozważania w: A. Pacholik-Żuromska (red.), Niemiecka analityczna filozofia umystu, Toruń 2011.

4 J. Vetulani, op. cit., s. 179.

5 Zob. ibidem, s. 135-136.

6 Ibidem, s. 59-60.

7 Ibidem, s. 18.

8 Ibidem. 
Idąc dalej, należy zaznaczyć:

Tak zwany „problem mózgu i duszy”, pytanie, czy świadomość ma materialną podstawę, był uważany za istotny od czasów starożytnych. Znaczenie problemu polega na tym, że jego rozwiązanie naładowane jest ideologią, a ponadto rodzi ważne konsekwencje praktyczne. Jest to szczególnie ważne dla psychiatrii, gdyż leczenie chorób psychicznych zależy od przekonań psychologa, psychoterapeuty, psychiatry dotyczących relacji między umysłem a ciałem.

Jest wiele ważnych aspektów, którymi neurobiologia moralności powinna się zająć - nie tylko istnieniem „wrodzonego zmysłu moralnego”, który byłby jej podstawą, ale przede wszystkim społecznymi implikacjami, takimi jak „neurobiologia agresji”"10 czy „,neurobiologia pamięci”"11.

Warto dodać, że już starożytni, jak Marek Aureliusz, zastanawiali się nad tym, czym jest umysł i od czego zależy nasze zachowanie moralne: ,Jeśli pierwiastek umysłowy (noeron) jest nam wspólny, to i rozum (logos), zgodnie z którym jesteśmy rozumni - wspólny; jeśli tak, to i rozum rozkazujący (prostaktikos), co robić, a czego nie - także jest wspólny"'12. Współcześnie badania są prowadzone na gruncie neuronauk, nie tylko filozofii i moralności. Panta rei.

Ostatnimi czasy nie tylko narodziła się bioetyka, lecz także właśnie przyszła na świat jej młodsza córka - neuroetyka (neuroethics). Bioetyka nie potrafi już udzielić odpowiedzi na wiele pytań. Odpowiada na nie właśnie neuroetyka. Problem w tytule niniejszego opracowania jest problemem zaiste neuroetycznym. Neuroetyka zajmuje się wpływem neuronauk na ludzkie postrzeganie siebie, etykę i politykę. Wiele zagadnień dotyczących funkcjonowania systemu nerwowego jest wciąż tradycyjnie badanych przez bioetykę, np. świadomość pacjenta i jego zgoda na zabieg. Jednak zupełnie poza bioetyką leży problem ludzkiej odpowiedzialności (personal responsibility) i to, jak powinniśmy o niej myśleć w kontekście osiągnięć neuronauk. Dotyczy to zwłaszcza wymiaru sprawiedliwości. Problem jest głęboko zakorzeniony w neuronaukach i filozofii prawa. Innym problemem, który wyszedł poza bioetykę, stając się problemem neuroetycznym, jest brain privacy (autonomia, prywatność mózgu). Dzięki wysoce zaawansowanym technologiom być może uda się odczytać, co czujemy i o czym myślimy w danym momencie (Czy to nie jest skanowanie mózgu i skanowanie naszych myśli? Dla niektórych jawi się to wciąż jako science fiction, ale dla neurobiologów, takich jak J. Vetulani, jest jasne, że „możliwości techniczne już w zasadzie istnieją, na szczęście jeszcze czasochłonność i koszty nie pozwalają na ich stosowanie"13). Jest to jednak również głęboki problem filozoficzny dotyczący granic ingerencji

\footnotetext{
9 Ibidem, s. 15.

${ }^{10}$ Por. ibidem, s. $105-132$.

${ }^{11}$ Por. ibidem, s. 195-229.

${ }^{12}$ M. Aureliusz, Rozmyślania (do siebie samego), Warszawa 2011, s. 74, pkt 4.4.

${ }^{13}$ J. Vetulani, op. cit., s. 136.
} 
w ludzką prywatność i wolność. Problemem neuroetycznym są także same podstawy myśli etycznej. Czasem bowiem ludzie uważają, iż zasady etyczne, moralne są transcendentne i leżą gdzieś poza ludzkim mózgiem (outside human brain). Neuroetyka wskazuje, że droga, jaką przeszedł nasz mózg w procesie ewolucji $\mathrm{i}$ to, jak on funkcjonuje, jest znamienna dla istoty naszego moralnego myślenia i dla istoty naszego myślenia o etyce w ogóle. Kolejny problem neuroetyczny jest najważniejszy z punktu widzenia tego opracowania. Dotyczy wszelkich interwencji (interventions) w ludzki mózg, które poprzez środki farmakologiczne, narkotyki (drugs) albo inne narzędzia i techniki inwazyjne mają wpłynąć na ludzkie poznanie (cognition) albo nawet zmienić (change) osobowość (personality). Problem ten wykracza poza bioetykę i etykę. Za neuroetykami można postawić pytanie: jeśli twój współmałżonek tak naprawdę lubi cię tylko jeśli jesteś na antydepresantach, to z jaką osobą zawarł związek małżeński? ${ }^{14}$

Zdaniem Stevena E. Hymana do najciekawszych tematów neuronauk należą: cognitive enhancement (kognitywne, poznawcze wzmocnienie), narkotyki i interwencje, które zmieniają ludzką tożsamość (person's identity), prywatność i autonomia mózgu (brain privacy), neuronowe podstawy moralności (neural basis of morality) i moralne poznanie (moral cognition), neurobiologia procesu decyzyjnego, która jest wykorzystywana np. w marketingu i w związku z tym dotyczy etyki ${ }^{15}$. Warto jeszcze wspomnieć inne ważne kwestie, takie jak neuroetyka a uzależnienie (addiction), głęboka stymulacja mózgu (deep brain stimulation), neuroetyka a bezpieczeństwo narodowe (national security), neuroetyka a wolna wola (free will), implikacje prawne nauk o mózgu. Zakres neuronauk jest szeroki. Dzięki jej osiągnięciom można skuteczniej walczyć ze społecznymi patologiami, np. z alkoholizmem czy innymi uzależnieniami (np. narkotyki).

Praktyczne znaczenie neuronauk jest ogromne, dotyczy m.in. następujących problemów: jak szeroko stosować farmakologię w leczeniu zaburzeń psychicznych lub wzmacnianiu poznawczym, jak wychowywać dzieci, co oznacza odpowiedzialność za czyny, co oznacza wymierzanie sprawiedliwości w sądzie, jak określać moralny status osób z poważnymi zaburzeniami psychicznymi czy uzależnionych od narkotyków, alkoholu itp. Badania na ten temat są coraz bardziej interdyscyplinarne. Do neuronaukowców w The International Neuroethics Society (Maryland, USA) dołączyli np. psycholodzy, filozofowie, bioetycy, prawnicy, zafascynowani tym, jak funkcjonuje ludzki mózg, myśli, emocje, kontrola behawioralna i jakie ma to implikacje społeczne, przełożenie na etykę i politykę,

${ }^{14}$ Zob. wiele na temat neuroetyki na stronie The International Neuroethics Society, a zwłaszcza wywiad z Stevenem E. Hymanem: www.neuroethicssociety.org/what-is-neuroethics (dostęp: 10.06.2013), z którego korzystam w tym miejscu.

${ }^{15}$ Ibidem. Ciekawą teorię o wartościach moralnych i ich emocjonalnych podstawach (Moral Foundations Theory) przedstawił też Jonathan Haidt, jeden z najbardziej znanych myślicieli amerykańskich i psychologów. Zob. też: J. Vetulani, op. cit., s. 26 (wywód w kontekście neurobiologii wyboru i dylematów moralnych). 
a zatem także na prawo. „Zbudowanie mostów między zaawansowanymi neuronaukami i światem polityki i etyki" jest celem tych uczonych ${ }^{16}$. Można w tym miejscu pominąć równie ważne wykorzystanie osiągnięć neuronauk w wojsku, co już jest faktem, mimo iż rodzi pewne etyczne pytania (np. wzmocnienie na polu bitwy - warfighter enhancement, ograniczenie cierpienia, wykrywacz kłamstw itp. ${ }^{17}$. Ujęcie publicystyczne tematyki funkcjonowania mózgu i rozszerzenie świadomości społecznej w tym przedmiocie również jest istotne ${ }^{18}$.

Trzeba przede wszystkim raz jeszcze podkreślić, że to, jak pracuje mózg i jakie są jego zaburzenia, jest niezwykle ważne ze społecznego punktu widzenia, gdyż ma ogromny wpływ na stabilizację i ład społeczny. Jako ciekawostkę można przytoczyć pewne dane dotyczące chorób psychicznych. Choroby psychiczne stanowią połowę wszystkich chorób w Wielkiej Brytanii, według raportu London School of Economics and Political Science. Ów raport, zwany też raportem Lorda Layarda, przygotowany przez interdyscyplinarny zespół naukowy i zalecający wiele zmian w polityce zdrowotnej rządu, odkrył, że terapia psychologiczna jest stosowana w sposób dyskryminacyjny (dostęp do niej jest ograniczony dla wielu pacjentów), mimo że jest skuteczna np. w leczeniu depresji i innych zaburzeń psychicznych (anxiety disorders) w ponad 40\% przypadków ${ }^{19}$.

W raporcie The Royal Society ze stycznia 2011 r. podkreślono za H. Greely’em $^{20}$, że „,neuronauka może radykalnie zmienić nie tylko nasze codzienne wyobrażenie o moralnej odpowiedzialności, ale także nasze pojęcia karnej i prawnej odpowiedzialności, i sposoby reakcji na wyrządzone zło"21. Dlaczego? A jak powinniśmy zareagować na taką odpowiedź po wyrządzeniu zła: „Mój mózg zmusił mnie do zrobienia tego"?22 Zdano sobie sprawę z filozoficznych

${ }^{16}$ Zob. strona internetowa The International Neuroethics Society, a zwłaszcza wywiad z Stevenem E. Hymanem, dyrektorem The Stanley Center for Psychiatric Research at the Broad Institute, a także Distinguished Service Professor of Stem Cell and Regenerative Biology: www.neuroethicssociety.org/what-is-neuroethics (dostęp: 10.06.2013).

${ }^{17}$ Zob. M. N. Tennison, J. D. Moreno, Neuroscience, ethics, and national security: The state of the art, „PLoS Biology” 2012, vol. 10, issue 3, s. 1-4; na stronie: www.plosbiology.org (dostęp: 10.06.2013); M. Wheelis, M. Dando, Neurobiology: A case study of the imminent militarization of biology, ,International Review of the Red Cross” 2005, vol. 87, no. 859, s. 553-568.

${ }^{18}$ Wywiad z prof. Włodzisławem Duchem: Dlaczego nie pamiętam, w jakiej sukience jest żona?, „Gazeta Wyborcza”, 8.09.2011.

${ }^{19}$ Zob. How Mental Health Loses Out in the NHS, report by The Centre for Economic Performance's Mental Health Policy Group; http://cep.lse.ac.uk/pubs/download/special/cepsp26.pdf (dostęp: 20.08.2012).

${ }^{20}$ Zob. H. Greely, The social effects of advances in neuroscience: Legal problems, legal perspectives, [w:] J. Illes (red.), Neuroethics: Defining the Issues in Theory, Practice and Policy, Oxford 2006.

${ }^{21}$ Zob. Brain Waves Module 1: Neuroscience, society and policy, report by The Royal Society, London, January 2011, s. 50; http://royalsociety.org/uploadedFiles/Royal_Society_Content/ policy/publications/2011/4294974932.pdf (dostęp: 20.08.2012).

${ }^{22}$ Ibidem. 
problemów w neuronaukach i problemu tożsamości człowieka ${ }^{23}$. Kto jest bowiem winien? Może nie człowiek, a mózg? Może jego należy ukarać? Ale jak? Późniejsze raporty nie podjęły tej radyklanej drogi, ograniczając się do konkretnych i zdroworozsądkowych wskazówek, jak neuronauka powinna współpracować z prawem.

The Royal Society ogłosiło raport w grudniu 2011 r., zalecając większą współpracę przedstawicieli nauk o mózgu i nauk społecznych, w tym nauk o prawie i praktyki wymiaru sprawiedliwości ${ }^{24}$. Wydaje się, że wnioski są tak uniwersalne, że nie dotyczą tylko Wysp Brytyjskich. Teoria płynąca z neuronauk powinna być przeniesiona na grunt praktyki prawa. Ale nie tylko, gdyż neuronaukowcy powinni więcej wiedzieć o społecznych konsekwencjach swoich badań i odkryć. Zgodnie z raportem „neuronaukowcy starają się odkryć, jak funkcjonowanie mózgu wpływa na zachowanie, a prawo jest zainteresowane regulacją zachowań" 25 . Jest zatem oczywiste, zdaniem twórców raportu, że rozwój neuronauk będzie miał ogromny wpływ na prawo, znajdując zastosowanie np. w takich kwestiach, jak: probacja i parole decisions (decyzje nadzorcze), detecting deceptions (zbadanie złej wiary, kamuflażu), assessing memory (wspomaganie pamięci), understanding pain (ból i rozumienie tego procesu), Non-Accidental Head Injury (NAHI, uszkodzenie mózgu u dzieci poprzez wstrząśnięcie dziecka). Według raportu:

1. „Występuje wielka luka (big gap) między badaniami prowadzonymi przez neuronaukowców a rzeczywistością (the realities) codziennego życia wymiaru sprawiedliwości (the justice system). Nie ma wspólnego forum w Wielkiej Brytanii, gdzie neuronaukowcy i prawnicy mogliby razem przedyskutować sprawy, które są objęte wspólnym zainteresowaniem"26, czyli brakuje współpracy między neuronauką a nauką prawa (i praktyką prawa).

2. „Jest ważne, aby prawnicy na wszystkich szczeblach porządku prawnego, których może dotyczyć neuronauka, zrozumieli podstawowe zasady, na których ona się opiera”, gdyż ,prawnicy i sędziowie w Anglii i Walii często nie mają żadnych kursów o tych zasadach. $Z$ kolei studenci w neuronaukach nie są nauczani o społecznych implikacjach tej dyscypliny"27.

3. „Prawie całość neuronaukowych badań w Wielkiej Brytanii jest związana ze zdrowiem. Jakkolwiek, wnioski płynące z tych badań mają szersze implikacje dotyczące polityki rządu" ${ }^{28}$. Ważne zwłaszcza wydają się badania o neuropatologii

${ }^{23}$ Ibidem, s. 49-50.

${ }^{24}$ Zob. Brain Waves 4: Neuroscience and the Law, report by The Royal Society, London, December 2011; http://royalsociety.org/uploadedFiles/Royal_Society_Content/policy/projects/ brain-waves/Brain-Waves-4.pdf (dostęp: 20.08.2012).

${ }^{25}$ Ibidem, s. vi i 34.

${ }^{26}$ Ibidem.

${ }^{27}$ Ibidem.

${ }^{28}$ Ibidem. 
dotyczące NAHI, badania dotyczące skuteczności (efficacy) w różnych modelach ryzyka $\mathrm{w}$ probacji, odkrycia $\mathrm{w}$ zakresie stymulacji pamięci, zastosowanie neuronauk wraz z istniejącymi już instytucjami ${ }^{29}$.

Na koniec warto jeszcze wskazać, że rewolucja nie jest jednak powszechnie proponowana na gruncie współpracy między neuronauką a prawem. W marcu 2013 r. w Oksfordzie ukazała się książka Neuroscience and Legal Responsibility pod redakcją australijskiej badaczki polskiego pochodzenia Nicole A. Vincent (będzie o niej jeszcze mowa w pkt 4 opracowania), pracującej na uniwersytecie Macquarie w Australii i na uniwersytecie technologicznym w Delft w Holandii ${ }^{30}$. Ta interdyscyplinarna praca, $\mathrm{z}$ dobrym historycznym podłożem, proponuje dialog między filozofią, neuronauką, psychologią i prawem. Jest jasne, że zasady odpowiedzialności prawnej zmieniały się w historii, także w systemie common law, a element psychiki, subiektywizacja winy, został dodany dopiero w XIII w. Opierając się wrażeniu „radykalnej reformy prawnej” i nie polegając na odrzuceniu „moralnych podstaw odpowiedzialności prawnej” na rzecz jakiegoś powszechnie panującego determinizmu, ale wykorzystując dokonania neuronauk w zakresie wiedzy o funkcjonowaniu mózgu i jego wpływie na zachowanie, N. Vincent i inni autorzy twierdzą, że neuronauki wpłyną na prawo (zwłaszcza wnioski z badań nad zachowaniami patologicznymi, ale także z badań nad ulepszeniem ludzkich umysłów i lepszym funkcjonowaniem mózgu itp.) i proponują jednak pewną debatę nad zmianą zasad odpowiedzialności prawnej, o której będzie mowa w kolejnych punktach opracowania (pkt 4 i 5). Otwierają zatem nowe wrota do debaty, która dla społeczeństwa może się wydać kontrowersyjna; wyłamują drzwi, niosąc nowe idee; czynią to jednak ,kuchennymi drzwiami” - jakby oddolnie albo po cichu. Niewiele wiemy o tych nowościach, projektach, badaniach, wnioskach i rekomendacjach, a są one bardzo ważne społecznie. O co chodzi?

\section{Wpływ badań nad mózgiem a zmiany zasad odpowiedzialności prawnej. Pytania i hipotezy}

W związku z rozwojem badań nad mózgiem i neuronauk zrodziły się też pytania o zmianę zasad odpowiedzialności prawnej przedstawicieli wybranych grup zawodowych (np. lekarzy, pilotów, żołnierzy). Realizowane są projekty (np. projekt uniwersytetów: Oksfordu i Delft - „Enhancing Responsibility: the effects of cognitive enhancement on moral and legal responsibility") dotyczące stworzenia rekomendacji dla zmian w prawie i etycznych kodeksach zawodowych, o czym będzie mowa dalej (pkt 4 i 5 opracowania).

${ }^{29}$ Ibidem.

${ }^{30}$ N. A. Vincent (red.), Neuroscience and Legal Responsibility, Oxford 2013 - zob. zwłaszcza rozdział wstępny, wprowadzający i historyczny, autorstwa Nicole Vincent. 
Powstają pytania: Jak wzmocnić/ulepszyć odpowiedzialność (to enhance responsibility)? Co uczynić z rezultatami kognitywnego/poznawczego wzmocnienia/ulepszenia (cognitive enhancement) na płaszczyźnie prawnej i moralnej odpowiedzialności?

Dwie kwestie są ważne:

1. Czy można kogoś wzmacniać poznawczo poprzez odpowiednie środki (psychofarmakologiczne) w jego pracy zawodowej?

1a. Jeśli tak, to czy stosować wobec tej osoby wyższe wymagania i ostrzejsze zasady odpowiedzialności prawnej? I stosować sankcje, jeśli ten ktoś się nie wzmocni, a powinien był i później okazało się, że popełnił jakiś błąd w pracy (prawdopodobnie na wskutek braku wzmocnienia)?

Rodzą się kolejne pytania. Jak ma się to do perfekcjonizmu etycznego?

2. Czy musimy być perfekcjonistami w naszej pracy zawodowej?

2a. Jeśli tak, dlaczego wymuszać to także prawem (powszechnym lub korporacyjnym, wewnętrznym, np. w kodeksach dobrych praktyk czy kodeksach etycznych)?

Po pierwsze, chciałbym podkreślić, że już wstępne myśli wskazują na interdyscyplinarność badań. Musimy prowadzić nie tylko prawne, lecz także medyczne, psychologiczne lub filozoficzne badania nad „nową” odpowiedzialnością i poznawczym ulepszeniem (np. poprzez narkotyki) dla członków wybranych zawodów. Efektem takiego podejścia są lub będą rekomendacje dla nowego prawa i kodeksów praktyk.

Jako filozof prawa i prawnik traktuję problem odpowiedzialności w prawie jako jeden z najpoważniejszych tematów w jurysprudencji. Dla prawnika jest absolutnie oczywiste, że pewni ludzie są odpowiedzialni prawnie, a inni nie są (dzieci, psychicznie chorzy, osoby działające w stanie wyższej konieczności itp.). Wydaje się, że stanowi to dobrze ugruntowaną tradycję i jest zasadą prawa w Europie.

Z drugiej strony - wydaje się, iż musimy szukać granic idei, że odpowiedzialność „podąża” (track) za zdolnością czy stanem psychicznym, zdolnościami mentalnymi, psychicznymi (mental capacity), np. inna jest odpowiedzialność dzieci czy osób z zaburzeniami psychicznymi. Pytanie brzmi jednak (stawia je N. Vincent): Co zrobić w sytuacji, gdy zdolności psychiczne wychodzą poza normalny poziom na skutek kognitywnego wzmocnienia? Jest to sytuacja ekstremalna, wyjątkowa, nadzwyczajna. I o nią tu chodzi.

Według zdefiniowanego celu tej pracy powinniśmy rozważyć sytuację przedstawicieli pewnych zawodów, takich jak chirurdzy, żołnierze, piloci. Czy mają obowiązek, by poznawczo wzmacniać samych siebie? Jeśli tak, to po takim kognitywnym ulepszeniu (enhancement) powinni oni mieć (ponosić) większą odpowiedzialność? ${ }^{31}$

${ }^{31}$ Zob. poglądy N. A. Vincent, Enhancing Responsibility, s. 429-472 (wersja przesłana przez autorkę w formie pdf, październik 2011). 
Teraz należy wziąć pod uwagę następujące przykłady. Przykład pierwszy: wyobraźmy sobie żołnierza podczas pełnej ryzyka operacji, który nie jest zdolny wykonać rozkazów z powodu braku takiego kognitywnego ulepszenia. To stanowi zagrożenie dla innych ludzi, np. ratowanych cywilów albo kolegów z oddziału. Co zrobić? Wzmocnić poznawczo żołnierza? Zmusić prawem do tego, by wziął narkotyki albo inne środki psychofarmakologiczne? (przecież wypicie kawy nie wystarczy, by wyjść poza normalny poziom zdolności psychicznych; trzeba pobudzić mózg poprzez środki psychofarmakologiczne).

Drugi przykład: kierowca w autobusie lub pilot w samolocie są pracownikami, którzy powinni wzmocnić, ulepszyć kognitywnie siebie, jeśli chcieliby być moralnie, nie tylko prawnie, odpowiedzialnymi osobami w stosunku do innych ludzi. Załóżmy, że kierowca nie jest odpowiednio skoncentrowany albo jest zmęczony, a prowadzi autobus z pięćdziesięciorgiem dzieci. Co zrobić? Wzmocnić poznawczo kierowcę? Zmusić prawem do tego, by wziął narkotyki albo inne środki psychofarmakologiczne?

Trzeci przykład: czy chirurg podczas zabiegu, operacji lekarskiej lub lekarz w swojej praktyce, dokonując diagnozy lub dając informację o np. poważnych chorobach lub o aborcji, prenatalnym prześwietleniu, sztucznym zapłodnieniu, eutanazji, powinien być poznawczo wzmocniony, ponieważ ważniejsze wartości - zdrowie i życie pacjenta - powinny być realizowane? Co zrobić? Wzmocnić poznawczo lekarza? Zmusić prawem do tego, by wziął narkotyki albo inne środki psychofarmakologiczne?

Widzę zatem trzy sfery profesjonalnej aktywności (podobne ujęcie występuje w opisie projektu Oksford-Delft; zob. także pkt 4 opracowania), które mogą być rozważone na polu obowiązku poznawczego ulepszenia, z zastrzeżeniem moich uwag zamieszczonych we wnioskach tego opracowania (zob. pkt 6):

1) transport i logistyka (np. piloci, kierowcy w publicznym lub prywatnym zbiorowym transporcie, specjaliści w obsłudze lotniska - ta aktywność dotyczy zdrowia i życia pasażerów);

2) wojsko, policja i służby specjalne (żołnierze, policjanci, agenci i pracownicy służb specjalnych - dotyczy wartości egzystencji państwa, jego niepodległości lub, bardziej ogólnie, dobrze zorganizowanego państwa, ładu i porządku publicznego);

3) relacje: prawo - etyka - medycyna (chirurdzy, lekarze, którzy są moralnie i prawnie odpowiedzialni za leczenie, ale w praktyce ktoś z nich mógłby powiedzieć, że obowiązek ten nie był dobrze zrealizowany z powodu bycia zmęczonym, a błędy się zdarzają; medycyna jest sztuką; poznawcze wzmocnienie przez narkotyki byłoby konieczne, jeśli nie chcemy widzieć dużo więcej błędów w leczeniu).

Podobne przykłady i sfery występują w projekcie badawczym, który będzie omówiony dalej. 


\section{Projekt uniwersytetów w Delft i Oxford. Teoria Nicole Vincent}

Godnym uwagi projektem badawczym dotyczącym zmian zasad odpowiedzialności prawnej w związku z odkryciami neuronauk jest wspomniany projekt uniwersytetów: uniwersytetu w Oksfordzie i uniwersytetu technologicznego z Delft pt. „Enhancing Responsibility: the effects of cognitive enhancement on moral and legal responsibility" ${ }^{32}$. Ma on na celu stworzenie rekomendacji dla zmian w prawie i etycznych kodeksach zawodowych. Koordynatorem projektu jest wspomniana australijska badaczka, filozofka specjalizująca się w neurolaw i neuroethics, Nicole A. Vincent. Celem praktycznym projektu jest odpowiedź na pytania: 1) czy osoby wykonujące niektóre zawody (np. chirurdzy, piloci, żołnierze) mają obowiązek moralny i prawny poznawczego wzmocnienia siebie (np. poprzez narkotyki); 2) jeśli tak, to czy można wymagać od nich więcej i zwiększyć granice ich odpowiedzialności prawnej; 3) czy jest niedbalstwem (negligence) albo niechlujstwem (reckless) z ich strony odmowa albo brak poznawczego wzmocnienia w pewnych sytuacjach; 4) czy można żąać od osób poznawczo wzmocnionych wyższego standardu staranności (np. pozbawiać prawa wykonywania zawodu, pociągać do odpowiedzialności cywilnej i karnej w razie błędu)? Celem teoretycznym projektu jest zbadanie granic idei, że odpowiedzialność podąża za zdolnością psychiczną (a gdy jej nie ma, nie ma też odpowiedzialności). Projekt zakłada również analizę historycznoprawną w celu zbadania, jak prawo reagowało na nowości technologiczne pojawiające się w przeszłości. Istotne są także pewne intuicje moralne i rozważania psychologiczne. Z punktu widzenia prawa analizuje się nowy standard wyższej staranności. Odnosi się go do podmiotów moralnie odpowiedzialnych (nie do np. dzieci, chorych psychicznie itp.). Projekt ma rzucić nowe światło na relacje między odpowiedzialnością a zdolnością psychiczną (mental capacity). Cel dalekosiężny projektu jest jasny - projekt powinien wpłynąć na środowisko profesjonalistów (np. medyczne), prawodawców, urzędników, sędziów i prawników w ten sposób, by rozwinęli nowe zasady odpowiedzialności w prawie.

Projekt odzwierciedla idee głoszone przez N. Vincent. Teorię N. Vincent zamierzam zrekonstruować $\mathrm{z}$ jej licznych publikacji ${ }^{33}$ oraz z korespondencji elektronicznej, którą prowadziłem z N. Vincent w latach 2011-2012. Ujmując rzecz krótko, N. Vincent uważa, że:

${ }^{32}$ Zob. stronę internetową projektu: http://enhancingresponsibility.com/?page_id=27 (dostęp: 10.06.2013).

${ }^{33}$ N. A. Vincent, Neurolaw and Direct Brain Interventions, „Criminal Law and Philosophy”, 6 June 2012, http://link.springer.com/article/10.1007\%2Fs11572-012-9164-y/fulltext.html (dostęp: 10.06.2013); eadem, Restoring responsibility: Promoting justice, therapy and reform through direct brain interventions, „Criminal Law and Philosophy”, 25 May 2012, http://link.springer.com/article/10.1007/s11572-012-9156-y/fulltext.html (dostęp: 10.06.2013); eadem, Responsibility, dysfunction and capacity, „Neuroethics” 2008, no. 1, s. 199-204; eadem, Neuroimaging and responsibility assess- 
1) jeśli cele, interesy (stakes) są ważne (np. życie, bezpieczeństwo), ludzie powinni „,wykonać dobrą robotę" (do their best), i

2) jeśli „bezpieczne i skuteczne środki wzmacniania siebie” (safe and effective means of enhancing ourselves) poprzez np. techniki psychofarmakologiczne (psychofarmacological techniques) są osiaggalne (available),

3) to obowiązek do their best zawierałby „obowiazzek wzmocnienia siebie” ( $a$ duty to enhance themselves), tj. istniałby obowiązek pobrania „poznawczych wzmacniaczy" (cognitive enhancers).

Ponadto N. Vincent sugeruje:

4) jest „całkowicie uzasadnione” (perfectly reasonable), aby „oczekiwać więcej” (expect more) od tych ludzi, którzy są bardziej „zdolni” (more capable), tj. są poznawczo wzmocnieni poprzez odpowiednie środki, o których mowa wyżej, i

5) mogłoby być uzasadnione również, aby te „Wzmocnione jednostki” (enhanced individuals) przyporządkować do „wyższego standardu staranności” (higher standard of care), tj. nie tylko oczekiwać od nich więcej, ale i zaostrzyć ich prawną odpowiedzialność w razie błędu i nienależytego wykonania zadania (albo braku poznawczego wzmocnienia mimo takiego obowiązku).

Te generalizacje mają doniosłe konsekwencje praktyczne. Można je odnieść do przykładów z pkt 3 opracowania, by wiedzieć, gdzie teoria ma zastosowanie.

\section{Rekomendacje zmian w prawie i polityce oraz odniesienie do spoleczeństwa}

Uczestnicy projektu Oxford-Delft, mimo iż zakładają, że cała teoria N. Vincent powinna być przełożona na język prawa i aktów prawnych, to mają świadomość pewnych społecznych trudności (widząc jednak pewne szanse dla rekomendacji zmian prawa):

1) pytania projektu dotyczą wolności osobistych profesjonalistów;

2) powstaje problem, czy mogą oni wybrać odmowę poznawczego wzmocnienia;

ments, „Neuroethics” 2011, no. 4, s. 35-49; eadem, What do you mean I should take responsibility for my own ill health?, „Journal of Applied Ethics and Philosophy” 2009, vol. 1, s. 39-51; eadem, On the Relevance of Neuroscience to Criminal Responsibility, 26 November 2009, http://ink.springer.com/ article/10.1007/s11572-009-9087-4/fulltext.html (dostęp: 10.06.2013); eadem, P. Haselager, G.-J. Lokhorst, “The Neuroscience of Responsibility” - Workshop Report, „Neuroethics”, 16 June 2010, http:// link.springer.com/article/10.1007/s12152-010-9078-0/fulltext.html (dostęp: 10.06.2013); eadem, Capacitarianism, responsibility and restored mental capacities, [w:] B. van der Berg, L. Klaming (eds), Technologies on the Stand. Legal and Ethical Questions in Neuroscience and Robotics, Nijmegen 2011, s. 41-62; eadem, Legal responsibility adjudication and the normative authority of the mind sciences, „Philosophical Explorations” 2011, vol. 14, no. 3, s. 315-331; eadem, The challenges posed to private law by emerging cognitive enhancement technologies, [w:] S. Muller, S. Zouridis, M. Frishman, L. Kistemaker (red.), The Law of the Future and the Future of Law, Oslo 2011, s. 511-521. 
3) jakie oczekiwania byłyby wówczas wobec nich i co należałoby uczynić, gdyby sprawy poszły źle;

4) obecne społeczeństwo jest źle ustosunkowane do powyższych kwestii i pytań, ponieważ nigdy nie spotkało się (ani na poważnie nie rozważało tej kwestii) z odpowiedzialnością osób, którzy mają wzmocnioną zdolność psychiczną, wychodzącą poza średni poziom (people with above-average mental capacities);

5) według najlepszej wiedzy twórców projektu dotychczas żaden profesjonalista nie został ukarany za niewybranie kognitywnego wzmocnienia ani za nieosiągnięcie wyższego standardu staranności podczas poznawczego wzmocnienia $^{34}$;

6) zatem nastał czas, aby przygotować społeczeństwo do debaty na ten temat;

7) chodzi o rozwinięcie rekomendacji dla polityki rządowej, dla rządu, prawodawców, sędziów w celu zmiany prawa; chodzi o rekomendacje dla środowisk profesjonalistów w celu zmiany (update) kodeksów dobrych praktyk (codes of conduct) poprzez nałożenie na członków korporacji obowiązku poznawczego wzmocnienia; chodzi także o wskazanie w tych rekomendacjach dróg, w których odbywać się będzie kontrola używania narkotyków (drugs), tak aby nie powodowały i nie tworzyły one nowych społecznych i prawnych problemów ${ }^{35}$.

Zatem podstawową rekomendacją jest nałożenie na członków korporacji ${ }^{36}$ i środowisk profesjonalistów (np. medycznych, transportowych, wojskowych) obowiązków kognitywnego wzmocnienia. Ma to się odbyć w drodze prawodawstwa autonomicznego tych korporacji i środowisk profesjonalistów, poprzez regulację w ramach kodeksów etyki deontologicznej. Postuluje się także sankcje wobec osób, które odmówią realizacji obowiązku (zakaz wykonywania zawodu?). Odpowiednie zmiany powinny nastąpić również w prawie państwowym. Niekiedy byłoby to konieczne, by potwierdzić zmiany zasad odpowiedzialności dokonane w korporacjach i środowiskach profesjonalistów, a niekiedy ze względów oczywistych, gdyż regulacja dotyczy sfery państwowej (np. służby specjalne, wojsko) albo ma ujednolicić praktykę zmian prawa i nowych standardów odpowiedzialności prawnej.

\footnotetext{
${ }^{34}$ Mam wątpliwości co do tego, czy nikt nie został ukarany w jakiś sposób, np. brakiem awansu, ale to tylko intuicja moralna.

${ }^{35}$ Zob. na temat social and policy relevance: http://enhancingresponsibility.com/?page $\mathrm{id}=13$ (dostęp: 10.06 .2013 ).

${ }^{36}$ Tytułem wyjaśnienia: $\mathrm{w}$ tym miejscu chodzi mi bardziej o korporacje np. medyczne (w sensie: działające na podstawie ustaw szczególnych wspólnoty ex lege z uprawnieniami władczymi wobec jej członków i ich uprawnień zawodowych, tj. „stowarzyszenia” profesjonalistów, np. lekarzy, czy samorządy, np. lekarskie), a nie o korporacje biznesowe. Ale nie wykluczam, że problem dotyczy zarazem korporacji biznesowych, które być może w swoich kodeksach dobrych praktyk i tzw. ładach korporacyjnych chętnie wprowadziłyby obowiązek poznawczego wzmocnienia dla pracowników (aby dobrze wykonać swoją pracę i poświęcić się w ten sposób firmie i klientowi) albo inne nowinki płynące z osiągnięć neuronauk (skanowanie myśli, wykrywacz kłamstw).
} 


\section{Zagrożenia płynące ze zmian w prawie. Wnioski}

Są też pewne problemy (w mojej opinii):

1. Po pierwsze: czy nie jest ograniczeniem prawa do prywatności i wolności, jeśli wymusimy poznawcze wzmocnienie twardym prawem (lub tylko miękkim)? Co z prawami człowieka? („Wszyscy ludzie rodzą się wolni i równi” - tak zaczyna się pewna Deklaracja z 1948 r.). Co ze zdrowiem tego, który bierze środki psychofarmakologiczne i jest poznawczo wzmocniony po to tylko, by chronić zdrowie innych? Czy on nie jest tu ofiara?? Co to znaczy „bezpieczne” środki psychofarmakologiczne? (Nie ma takich!). Jak usprawiedliwić taką regulację? Innymi ludzkimi wartościami, takimi jak życie, zdrowie? Moralnością? Etyką deontologiczną?

2. Drugim problemem wydaje się to, jak odpowiedzialnie opisać granice zwiększonej odpowiedzialności dla pewnych profesjonalistów i potencjalne sankcje. Prawo nie daje nam odpowiedzi, ale być może powinniśmy analizować, jak pewne technologie i techniki, które się pojawiały, wpływały na prawo (np. w systemie kontynentalnym czy common law) w przeszłości i per analogiam możemy szukać podobnych środków prawnych w przyszłości.

3. Czy nie jest ingerencją prawa w sferę moralności inkorporowanie perfekcjonistycznej zasady etycznej, takiej jak nałożenie obowiązku poznawczego wzmocnienia, które ma na celu wykonanie ,jak najlepszej roboty”? Gdyby wprowadzono absolutny zakaz aborcji, budziłoby to kontrowersje, a gdy wprowadzimy taki obowiązek poznawczego wzmocnienia, czy nie będzie to tak samo kontrowersyjne ${ }^{37}$ A może wykładowca akademicki przed 10-godzinnym maratonem zajęć powinien wzmocnić się poznawczo, a dziekan wydziału prawa, wykonując uchwałę senatu, wydać stosowne zarządzenie w tej sprawie i regulować, jakie środki psychofarmakologiczne trzeba stosować? Brzmi to paranoicznie, uniformistycznie, technicystycznie, totalitarnie i antywolnościowo.

Uważam, że oczywiście istnieją pewne wysoce moralne wartości (np. życie i zdrowie pacjenta czy w ogóle człowieka, bezpieczeństwo państwa itp.), które mogłyby być dobrym uzasadnieniem dla nowego prawa dla pewnych grup zawodowych na polu enhancing responsibility (wzmocnienia/ulepszenia odpowiedzialności). Prawo powinno jednak być związane z opinią publiczną. Tony Honore pisał, że: „Prawo rości sobie pretensje do bycia moralnym, do tego, by brzmieć moralnie - do bycia częścią moralności. Próbuje kształtować moralną opinię" ${ }^{38}$. W mojej opinii moralność wciąż się zmienia i czasami prawodawcy powinni pokazać opinii publicznej poważne argumenty pro, idee za zmianą starego prawa. Jest prawdą, że ,prawo odgrywa ważną rolę w tworzeniu

${ }^{37}$ Por. D. Bunikowski, Podstawowe kontrowersje dotyczace ingerencji prawa $w$ sferę moralności, Toruń 2010.

${ }^{38}$ T. Honore, About Law. Introduction, Oxford 1995, s. 4. 
i utrzymywaniu społecznego ładu"39. Zatem aspekt roli prawa i jego moralne oraz etyczne konotacje są niesamowicie ważne w przedmiocie zmian zasad odpowiedzialności.

Nowe prawo jest potrzebne, jeśli nadchodzi nowa technologia - spójrzmy na uzasadnienie w Airedale N.H.S. Trust vs. Bland (1993) ${ }^{40}$. Lord Brown-Wilkinson absolutnie słusznie zauważył, że „Śmierć w tradycyjnym sensie była poza ludzką kontrolą" i nowe technologie (możliwości medyczne) zmieniły to. Lord Lowry spuentował, że istnieje możliwość „luki” między „starym prawem i nową medycyną i może... nową etyką"41. Zgadzam się z koniecznością jakichś zmian w prawie lub praktyce (np. lepsza organizacja pracy, by uniknąć błędów; jeśli zaś występują, to powstałaby konieczność wysokich odszkodowań, gdy analizujemy m.in. sprawy błędów lekarskich w brytyjskim case study, takie jak Gregg vs. Scott (2005, 4 All ER 812) lub w amerykańskich przypadkach, jak np. Darling vs. Charleston Community Medical Hospital (1996, 211 N. E. 2d 253), Jeanne vs. Hawkes Hospital of Mt Carmel (1991, 598 N. E. 2d 1174), Faya vs. Almaraz (1993, 620 A. 2d 327). Te przykłady dotyczą tylko medycyny, a przecież kwestia bezpieczeństwa w transporcie albo bezpieczeństwa państwa są równie doniosłe. Ale powinniśmy być rozważni w dokonywaniu zmian w prawie. „Pamiętaj!” - to było ostanie słowo wypowiedziane w innym kontekście niż ten, na szafocie, przez króla Karola I Stuarta do przyjaciela, biskupa Juxtona. Pamiętajmy o ludzkiej godności. Jak naprawdę głęboko moralnie usprawiedliwić obowiązek prawny, by ulepszać poznawczo samych siebie przez narkotyki czy inne środki medyczne? Widzę wiele moralnych, etycznych, a nawet aksjologicznych problemów dotyczących enhancing responsibility. Zdaję sobie sprawę, że faktyczne zmiany odpowiedzialności w prawie i etyce zawodowej już obecnie występują, np. w wojsku, służbach specjalnych, może też w transporcie (piloci pracujący dla firmy lotniczej!), przypuszczalnie również w innych dziedzinach (piłkarze w klubie piłkarskim?). Pewne pragmatyczne, w istocie mniej moralne, wartości są usprawiedliwieniem (np. dobrobyt, pieniądze, sława). Projekt oksfordzko-holenderski, dotyczący rekomendacji zmian prawa, zawiera wzniosłe hasło: „Z wielką władzą przychodzi wielka odpowiedzialność”. Czy na pewno?

Rozumiejąc argumenty za zmianą i starając się wczuć w role ich twórców, przedstawiam filozoficzne podstawy argumentów przeciw zmianom. Słowa Mikołaja Bierdiajewa brzmią w tym kontekście bardzo pięknie i mądrze dla zwolenników indywidualizmu, wolności i prywatności, takich jak piszący te słowa, i jednocześnie dla przeciwników praktycznych realizacji wizji odpowiadających na wszelkie potrzeby risk society:

\footnotetext{
${ }^{39}$ G. Slapper, D. Kelly, English Law, London 2000, s. 1.

${ }^{40}$ Orzeczenie publikowane w: „Medical Law Review” 2000, vol. 8, no. 3, s. 300-315.

${ }^{41}$ Ibidem.
} 
Wolność rodzi zło, ale bez wolności nie ma również dobra. Przymusowe dobro nie byłoby dobrem. W tym właśnie tkwi podstawowa sprzeczność wolności. Wolność czynienia zła jest warunkiem wolności czynienia dobra. Zlikwidujcie przemocą zło, a nic nie pozostanie dla wolności dobra. Oto dlaczego Bóg znosi istnienie zła. Wolność rodzi tragedię życia i cierpienie życia. Dlatego wolność jest trudna i surowa. Wolność jest najmniej łatwą sprawą w życiu i życie w wolności też nie jest łatwym życiem. Łatwiej żyć w konieczności. Fiodor Dostojewski, który wypowiedział bardzo głębokie myśli o wolności, zakładał, że najtrudniej człowiekowi jest znieść wolność ducha, wolność wyboru. Człowiek bardzo łatwo rezygnuje z wolności w imię złagodzenia cierpień życia poprzez przymusową organizację dobra (przymus w teokracji i przymus w systemie komunistycznym). Błędem byłoby sądzić, że człowiek szczególnie troszczy się o wolność. Przeciwnie, człowiek uważa wolność za fatalny dar i wcale nie broni wolności $[\ldots]^{42}$.

Podobne stanowisko zajął John Stuart Mill, negując państwowy czy społeczny paternalizm i apoteozując wolność człowieka oraz jego prawo do prywatności. W słynnym eseju J. S. Mill grzmi: „What, then, is the rightful limit to the sovereignty of the individual over himself? Where does the authority of society begin? How much of human life should be assigned to individuality, and how much to society?" "43. Jak dużo należy do indywidulanego człowieka, a jak dużo do społeczeństwa? Wskazuje na zasadę: mogę czynić wszystko, o ile nie wyrządzam komuś krzywdy (fizycznej). Podobnie Immanuel Kant opowie się przeciwko regulacjom paternalistycznym, wybierając zasadę wolności: granicą mojej wolności jest wolność drugiego człowieka ${ }^{44}$.

Manipulacja człowiekiem poprzez środki psychofarmakologiczne byłaby zatem złem moralnym, godzącym w ludzką godność, nawet jeśli ma to jawny bądź ukryty cel paternalistyczny. Ponadto trudno sobie nawet wyobrazić np. skanowanie myśli w stosunkach pracy czy w prawie karnym, gdzie panuje zasada in dubio pro reo. Jak zatem wytłumaczyć i uzasadnić działalność i interwencję państwa czy innych wspólnot (np. korporacji, stowarzyszeń profesjonalistów, a nawet biznesu i innych autonomicznych wspólnot)? Jest to problem filozoficzny i moralny.

Tak, można kogoś przymusić do poznawczego wzmocnienia (np. lekarza do wzięcia środków farmakologicznych, narkotyków) w imię czyjegoś dobra i paternalizmu (np. chodzi o dobro lekarza i pacjenta) oraz faktu, że żyjemy w słynnym Beckowskim społeczeństwie ryzyka (zresztą, co wskazał tak dobitnie Adam Czarnota w swoich pytaniach po moim referacie na Zjedzie

${ }^{42}$ M. Bierdiajew, Metafizyczny problem wolności, [w:] idem, Głoszę wolność. Wybór pism, Warszawa 1999, s. 59. Myśl tę poniekąd kontynuował J. Tischner, Nieszczęsny dar wolności, Kraków 1993.

${ }^{43}$ J. S. Mill, On liberty, [w:] R. A. Wasserstrom (ed.), Morality and the Law, Belmont-Wadsworth 1971, s. 11.

${ }^{44}$ Zob. I. Kant, O porzekadle: To może być stuszne w teorii, ale nic nie jest warte w praktyce. Do wiecznego pokoju. Projekt filozoficzny, Toruń 1995. 
w Łodzi we wrześniu 2012 r., bagatelizując moje personalistyczne ostrzeżenia w imię technicznych i paternalistycznych idei), które wszak należy nieustannie ograniczać, ale... moje pytanie jest otwarte: gdzie tu jest wolność?

Gdzie tu jest miejsce na wolną wolę, ludzki błąd, piękno (piętno?) ludzkiej wolności i piętno (piękno?) ludzkiej odpowiedzialności? Być może nigdy nie udzielimy prawidłowej odpowiedzi na to pytanie, jeśli zapomnimy o wolności na rzecz paternalizmu. Neuronauka wykracza poza dotychczasowe ujęcia prawne $i$ etyczne, ale w gruncie rzeczy problem jest stary i filozoficzny: co dalej z osobistą wolnością? Ile można oddać (być zmuszonym w świetle prawa) ze swej osobistej wolności na rzecz dobra wspólnego czy dobra drugiego człowieka? 